\title{
PERAN KELUARGA DALAM MENUMBUHKAN JIWA WIRAUSAHA SEJAK USIA DINI
}

\author{
Mallevi Agustin Ningrum \\ Jurusan PG PAUD, Fakultas Ilmu Pendidikan, Universitas Negeri Surabaya \\ E-mail: malleviningrum@unesa.ac.id
}

\begin{abstract}
Abstrak
Modal utama menjadi wirausaha yang sukses adalah motivasi yang kuat dari dalam diri individu disamping keberanian dalam mengambil resiko, ketekunan dan keuletan dalam menjalankan usahanya. Hal tersebut akan terwujud apabila jiwa entrepreneur dapat dipupuk sejak usia dini. Tentunya di sini peran keluarga sangat besar karena keluarga merupakan pendidik yang pertama dan utama bagi anak. Usia dini merupakan masa yang sangat penting dalam pembentukan pola bagi kehidupan anak di masa yang akan datang. Pada masa inilah peran orangtua sangat diperlukan dalam membentuk pola kehidupan mereka yaitu dengan cara menanamkan nilai-nilai moral agama, memotivasi untuk rajin belajar sehingga harapannya nanti ketika sudah dewasa dapat menjadi orang yang sukses, serta mendidik anak dengan jiwa berwirausaha sehingga ketika dewasa nanti mereka akan menyadari pentingnya penanaman moral agama, kepribadian, dan tidak bergantung pada orangtua dari segi finansial. Salah satu cara untuk menstimulasi tumbuhnya jiwa wirausaha anak sejak dini melalui bermain dan pembiasaan. Untuk itu, peran ayah sebagai kepala keluarga harus dapat mendukung peran ibu yang tugas utamanya mengasuh dan mendidik anak agar jiwa wirausaha dapat dipupuk sejak usia dini. Keluarga berperan sangat besar dalam menanamkan jiwa wirausaha sejak dini dengan melibatkan kerjasama kedua orangtua.
\end{abstract}

Kata Kunci: Keluarga, Jiwa Wirausaha, Usia Dini.

\section{Abstract}

The main capital to become a successful entrepreneur is a strong motivation from within the individual in addition to the courage in taking risks, perseverance and tenacity in running his business. It will be realized if the entrepreneurial spirit can be nurtured from an early age. Certainly here the role of the family is very large because the family is the first and main educator for the child. Early age is a very important time in the formation of patterns for the life of children in the future. At this time the role of parents is necessary in shaping the pattern of their lives that is by inculcating the moral values of religion, motivate to study diligently so that later when adult expectations can become a successful person, and educate children with entrepreneurial spirit so that when they grow up they will Realize the importance of religious moral planting, personality, and not dependent on the parent in financial terms. One way to stimulate the growth of child entrepreneurial spirit from an early age through play and habituation. To that end, the role of father as head of the family should be able to support the role of the mother whose main task is to nurture and educate the child so that entrepreneurial spirit can be nurtured from an early age. The family plays a very big role in instilling entrepreneurial spirit from an early age by involving the cooperation of both parents.

Keywords: Family, Entrepreneurial Spirit, Early age.

\section{PENDAHULUAN}

Pendidikan dan pengasuhan bagi anak merupakan tanggung jawab yang besar bagi orangtua. Hal itu sesuai dengan paparan Tafsir (2007:74) bahwa dalam keluarga orang yang paling bertanggungjawab terhadap pendidikan anak adalah orangtua. Tanggung jawab itu disebabkan karena alasan sebagai berikut: 1) secara kodrati orangtua ditakdirkan bertanggung jawab mendidik anak-anaknya, 2) orangtua berkepentingan terhadap kemajuan perkembangan anaknya. Peran ayah dan ibu memegang peranan sangat penting dan berpengaruh pada pendidikan anaknya. Pada dasarnya setiap manusia sudah dibekali dengan sifat-sifat kewirausahaan sejak lahir yaitu sudah nampak keberanian, kreativitas, dan inisiatif. Anak mengalami proses tumbuh kembang yang bervariasi, sehingga tidak semua anak dibekali dengan nilai-nilai hidup yang positif, kreatif, dan dinamis. Padahal posisi dan peran keluarga sebagai pendidik yang pertama dan utama yang meletakkan pondasi dasar bagi tumbuh kembang personalitas serta kematangan berpikirnya. Pendidikan yang diterima oleh anak dari keluarga yang kurang berperan menyebabkan anak-anak mudah terombangambing karena mudah tergoncang dengan pengaruh lingkungan. Untuk itu, keluarga memiliki peran besar dalam menumbuhkan pribadi-pribadi yang unggul demi kemajuan suatu masyarakat, bangsa, dan negara. Jiwa yang unggul ini sangat diperlukan dalam kewirausahaan.

Kewirausahaan yang dilakukan oleh seseorang tidak ada patokan dari segi usia. Oleh sebab itu, sejak usia dini jiwa berwirausaha sebaiknya sudah harus ditanamkan. Di kalangan etnis Tionghoa misalnya, mereka mulai 
dilibatkan dengan kegiatan berwirausaha orangtuanya dari kecil, kemudian pada waktu dewasa melanjutkan usaha yang dirintis oleh orangtuanya atau bahkan membuka peluang usaha mandiri. Jiwa berwirausaha tidak hanya diperlukan untuk berbisnis saja, namun sudah masuk ke semua bidang. Jiwa berwirausaha seperti semangat kerja, kreativitas, disiplin, inovatif, gigih, tidak mudah putus asa merupakan karakteristik jiwa unggu yang diperlukan di semua bidang. Hal ini senada dengan Suryana (2005:4) yang menyatakan bahwa ciri-ciri wirausahawan yang sukses adalah mereka yang berkompeten dalam bidang ilmu pengetahuan, keterampilan, dan kualitas individu itu sendiri meliputi motivasi, nilai, sikap, serta tingkah laku yang yang diperlukan dalam melakukan kegiatan.

\section{PEMBAHASAN}

\section{Hakikat Keluarga}

Keluarga merupakan kelompok kecil yang terdiri dari pemimpin dan anggotanya di mana di dalamnya terdapat peran dan fungsi masing-masing dalam hal pembagian tugas dan kerja serta hak dan kewajiban bagi masingmasing anggotanya. Keluarga merupakan tempat pertama dan utama bagi anak untuk belajar berbagai hal. Dari keluarga pula, anak dapat mempelajari sifat-keyakinan, sifat-sifat mulia, komunikasi dan interaksi sosial, serta keterampilan hidup. Hal itu didukung oleh pendapat Helmawati (2014:43) mengemukakan syarat-syarat keluarga ideal sebagai berikut: 1) perkawinan harus sah menurut agama dan hukum negara, 2) menikah dengan pasangan yang memiliki keyakinan yang sama, 3) memiliki anggota keluarga yang lengkap (ayah, ibu, anak), 4) tujuan berkeluarga adalam memiliki keturunan, 5) harus saling mengenal setiap pasangan, 6) pasangan harus hidup bersama dengan cinta dan kasih sayang sehingga ada ikatan batin, 7) Setiap angggota keluarga hendaknya menciptakan dan merasakan hidup tenterambahagia, 8) Setiap anggota memiliki hak dan kewajiban masing-masing serta saling menghormati antara satu dengan yang lainnya, 9) anggota keluarga perlu membuat pembagian tugas sesuai dengan porsinya, 10) memiliki waktu yang cukup untuk berkumpul bersama, 11) Komunikasi yang lancar dalam keluarga, 12) perlu ada bimbingan, pembinaan, dan pengawasan dalam keluarga.

\section{Peran Keluarga}

Tiga tempat pendidikan yang dapat membentuk anak menjadi manusia seutuhnya adalah di keluarga, sekolah, dan masyarakat. Keluarga adalah tempat titik tolak perkembangan anak. Peran keluarga sangat dominan untuk menjadikan anak yang cerdas, sehat, dan memiliki penyesuaian sosial yang baik. Keluarga merupakan salah satu faktor penentu utama dalam perkembangan pendidikan anak disamping faktor-faktor yang lain. Menurut Goode (1995), keberhasilan atau prestasi yang dicapai siswa dalam pendidikannnya tidak hanya memperhatikan mutu dari institusi pendidikan saja, tetapi juga memperhatikan keberhasilan keluarga dalam memberikan anak-anak mereka persiapan yang baik untuk pendidikan yang dijalani. Keluarga adalah institusi sosial yang ada dalam setiap masyarakat. Oleh karena itu, keluarga menjadi institusi terkuat yang dimiliki oleh masyarakat. Keluarga merupakan lingkungan pertama bagi anak. Di dalam lingkungan keluarga, anak pertama kali mendapatkan berbagai pengaruh (nilai). Oleh karena itu, keluarga merupakan lembaga pendidikan tertua yang bersifat informal dan kodrati. Ayah dan ibu dalam keluarga sebagai pendidiknya dan anak sebagai si terdidik. Keluarga sebagai lingkungan pendidikan yang pertama sangat berpengaruh dalam membentuk pola kepribadian anak. Di dalam keluarga, anak perama kali berkenalan dengan nilai dan norma. Pendidikan keluarga memberikan pengetahuan dan keterampilan dasar, agama, dan kepercayaan, nilai-nilai moral, norma sosial dan pandangan hidup yang diperlukan anak. Nilai-nilai moral di sini merupakan bekal sebagai jiwa berwirausaha pada saat anak sudah dewasa nanti.

\section{Metode dalam Proses Pendidikan di Keluarga}

Beberapa metode yang dapat digunakan untuk menanamkan jiwa berwirausaha pada usia dini sebagai berikut: 1) Metode internalisasi merupakan upaya untuk memasukkan pengetahuan dan keterampilan melaksanakan pengetahuan ke dalam diri seseorang sehingga pengetahuan itu menjadi kepribadian dan diimplentasikan dalam kehidupan sehari-hari. Hal ini sejalan dengan pendapat Tafsir (2011) bahwa upaya internalisasi berupa menyatukan pengetahuan dan keterampilan dengan diri pribadi individu dari daerah eksternal ke daerah internal. Jadi dapat disimpulkan bahwa proses pendidikan itu tidak hanya terletak pada penyampaian pengetahuan saja (teori) tetapi juga melatih keterampilan berdasarkan pengetahuan tersebut (praktek). Misal: anak memahami konsep dan definisi disiplin, di samping itu anak juga terampil menerapkan disiplin dalam kehidupan sehari-harinya, 2) Metode pembiasaan merupakan metode lain yang relatif efektif dalam menumbuhkan jiwa berwirausaha adalah melalui pembiasaan. Pentingnya menekankan metode pembiasaan ini pada anak usia dini merupakan cara yang tepat dalam menanamkan jiwa-jiwa berwirausaha. Oleh karena itu, jika anak sudah dibiasakan melakukan hal-hal yang baik sejak kecil, maka anak akan tumbuh dalam kebaikan. Senada dengan pendapat di atas, Daradjat (2007:147) menyebutkan bahwa pembiasaan tingkah laku yang baik pada anak sebaiknya dilakukan sejak kecil,seperti membiasakan tidur lebih cepat, membiasakan berolahraga, membiasakan jangan membuang sampah di sembarang tempat, membiasakan berkata jujur, membiasakan banyak bersedekah, membiasakan belajar sebelum tidur. Sehingga dapat disimpulkan bahwa apabila metode pembiasaan sudah diterapkan dengan baik dalam keluarga, maka akan lahir anak-anak yang baik dan dapat menjadi teladan bagi orang lain, 3) Metode bermain merupakan cara yang paling tepat untuk mengembangkan kemampuan anak sesuai kompetensinya. Anak memperoleh dan memproses informasi mengenai hal-hal baru dan berlatih melalui 
keterampilan yang ada. Anak-anak senantiasatumbuh dan berkembang. Mereka menampilkan ciri-ciri fisik dan psikologis yang berbeda untuk tiap tahap perkembangannya. Masa anak-anak merupakan masa puncak kreativitasnya. Kreativitas itu perlu dijaga dan dikembangkan dengan menciptakan lingkungan yang menghargai kreativitas yakni melalui bermain. Oleh karena itu, pendidikan di rumah yang menekankan belajar sambil bermain dapat mendorong anak untuk mengeluarkan semua daya kreativitasnya, 4) Metode cerita merupakan salah satu yang dapat digunakan dalam menanamkan jiwa berwirausaha sejak usia dini. Metode bercerita memiliki banyak manfaat, karena metode ini bertumpu pada bahasa, baik lisan maupun tulisan. Selain dapat mengembangkan imajinasi otak anak, metode bercerita juga dapat memberikan pesan moral yang terdapat dalam isi cerita. Sependapat dengan hal tersebut Salim (2013:262) menyatakan bahwa inti bercerita adalah dapat membentuk jiwa/karakter anak secara tidak langsung, 5) Metode keteladanan merupakan ungkapan tersebut seharusnya disadari oleh para orangtua, sehingga mereka lebih bisa menjaga sikap dan tindakannya ketika berada atau bergaul dengan anak-anaknya. Berbagi keteladanan dalam mendidik anak menjadi sesuatu yang sangat penting. Secara psikologis, anak memang sangat membutuhkan panutan atau contoh dalam keluarga. Sehingga dengan contoh tersebut anak dapat mengaplikasikan dalam kehidupan sehari-hari. Oleh karena itu, seorang anak akan tumbuh dalam kebaikan dan memiliki karakter yang baik jika melihat orangtuanya memberikan teladan yang baik, 6) Metode nasihat merupakan metode lain yang dianggap representatif dalam membina karakter anak melalui nasihat. Metode nasihat ini merupakan penyampaian kata-kata yang menyentuh hati dan disertai dengan keteladanan. Dengan demikian, metode ini memadukan antara metode ceramah dan keteladanan, namun lebih diarahkan kepada bahasa hati, tetapi bisa pula disampaikan dengan pendekatan rasional (Syarbini, 2012:85), 7) Metode penghargaan dan hukuman merupakan metode yang penting untuk dilakukan karena pada dasarnya setiap orang dipastikan membutuhkan penghargaan dan ingin dihargai. Anak adalah fase perkembangan manusia yang sangat membutuhan penghargaan. Oleh karena itu, jika anak dapat melakukan hal-hal yang terpuji selayaknya ornagtua memberikan apresiasi penghargaan. Selain penghargaan, metode hukuman juga dapat diterapkan. Namun perlu digarisbawahi bahwa metode hukuman sebenarnya kurang baik jika diterapkan dalam pendidikan, terlebih untuk mendidik anak. Sebab dengan adanya hukuman biasanya anak melakukan sesuatu dalam keterpaksaan karena takut hukuman. Metode hukuman ini dapat diterapkan jika seluruh metodemetode sebelumnya tidak berhasil.

\section{Jiwa Wirusaha}

Konsep kewirausahaan sampai saat ini masih terus berkembang. Kewirausaahan itu sendiri merupakan jiwa, sikap, kemampuan untuk menciptakan sesuatu yang baru dan sangat bernilai dan berguna bagi dirinya dan orang lain di sekitarnya. Sedangkan wirausaha merupakan orang yang terampil dalam mengembangkan usahanya dan memanfaatkan kesempatan dengan tujuan meningkatkan taraf hidupnya. Menurut Norman (2009), "An entrepreneur is one who creates a new business in the face of risk........". Wirausahawan merupakan orang yang memiliki kemampuan untuk melihat dan menilai kesempatan dalam berbisnis, mengumpulkan sumber daya yang dibutuhkan untuk mengambil tindakan yang tepat, mengambil keuntungan untuk mewujudkan gagasan inovatif ke dalam dunia nyata secara kreatif dalam rangka meraih kesuksesan. Sehingga wirausaha adalah orang yang mempunyai jiwa kreativitas dan inovatif yang tinggi dalam hidupnya. Dari uraian di atas, maka dapat disimpulkan bahwa kewirausahaan diidentikkan dengan kemampuan para wirausaha dalam dunia usaha, sedangkan wirausaha merupakan sesorang yang melakukan upaya kreatif dan inovatif dengan jalan mengembangkan ide untuk menemukan peluang dan peningkatan taraf hidup. Pernyataan tersebut didukung oleh pendapat Suryana (2001) bahwa kewirausahaan itu muncup pada diri individu yang berani mengembangkan usaha-usaha dan ide-ide barunya. Proses kewirausahaan meliputi semua fungsi dan tindakan yang berhubungan dengan pemerolehan kesempatan dan penciptaan dunia usaha. Esensi dari kewirausahaan adalah menciptakan nilai tambah melalui proses pengkombinasian sumber daya dengan cara baru dan berbeda dengan yang lain sehingga dapat berdaya saing. Nilai tambah tersebut dapat diperoleh melaui cara-cara sebagai berikut: 1) pengembangan teknologi baru, 2) penemuan pengetahuan baru, 3) perbaikan produk (barang dan jasa) yang sudah ada, 4) penemuan cara-cara yang berbeda untuk menghasilkan barang dan jasa yang lebih banyak dengan sumber daya yang lebih sedikit.

\section{Peran Keluarga Dalam Menumbuhkan Jiwa Wirausaha Sejak Dini}

Orangtua memiliki peran yang besar dalam memberikan proses pendidikan dan pengasuhan kepada anaknya. Membekali anak dengan nilai-nilai moral agama, pengetahuan umum saja tidak cukup untuk memberikan bekal kehidupan sampai nanti dewasa. Untuk itu, orangtua perlu membekali anak dengan kemampuan berwirausaha. Potensi berwirausaha pada setiap anak itu berbeda-beda sehingga sejak usia dini perlu ditumbuhkan jiwa berwirausaha dengan hal-hal yang sederhana dan menggunakan metode pembiasaan dan bermain. Di bawah ini ada beberapa hal yang dapat menumbuhkan jiwa wirausaha dapat tertanam pada diri anak sejak dini, antara lain: 1) Mengasah jiwa kepemimpinan anak, 2) Menumbuhkan cara berpikir kreatif, 3) Mendidik anak dengan memikirkan resiko, 4) Melatih kecakapan hidup (life skill), 5) Motivasi orangtua. Upaya orangtua di atas juga dapat diterapkan melalui metode internalisasi yang dikemukakan oleh Tafsir (2011) bahwa upaya internalisasi berupa menyatukan pengetahuan dan keterampilan dengan diri pribadi individu dari daerah eksternal ke daerah internal. Sehingga jiwa wirausaha 
dapat ditanamkan kepada anak melalui aktivitas seharihari mereka melalui metode internalisasi. Di samping itu, metode yang dapat diterapkan oleh orangtua adalah metode pembiasaan yang dikemukakan oleh Daradjat (2007:147) bahwa pembiasaan tingkah laku yang baik pada anak sebaiknya dilakukan sejak kecil. Sehingga dapat disimpulkan bahwa apabila metode pembiasaan sudah diterapkan dengan baik dalam keluarga, maka akan lahir anak-anak yang baik dan dapat menjadi teladan bagi orang lain. Jika dikaitkan dengan keiwarusahaan, maka sebagai orangtua perlu memilih metode yang tepat dalam menanamkan jiwa berwirausaha sejak dini. Hal ini mendukung pendapat dari Suryana (2005:4) yang menyatakan bahwa ciri-ciri wirausahawan yang sukses adalah mereka yang berkompeten dalam bidang ilmu pengetahuan, keterampilan, dan kualitas individu itu sendiri meliputi motivasi, nilai, sikap, serta tingkah laku yang yang diperlukan dalam melakukan kegiatan. Pendapat tersebut tentunya diawali dari lingkungan keluarga karena anak setiap hari berinteraksi sosial dengan anggota keluarga, khususnya ayah dan ibu. Peran keluarga menjadi besar bagi pendidikan anak, karena keluarga itu sendiri merupakan pondasi pertama dan lingkungan yang utama bagi anak dalam mengembangkan semua potensi yang ada dalam dirinya.

\section{PENUTUP}

\section{Simpulan}

Simpulan dari beberapa pendapat yang sudah dipaparkan sebelumnya antara lain: 1) Secara umum, pendidikan dalam keluarga berperan dalam menumbuhkan jiwa wirausaha pada anak karena wirausahawan yang sukses pada umumnya dipicu oleh orangtuanya baik secara langsung maupun tidak, 2) Kebanyakan ibu berperan sebagai orangtua yang dominan dalam mengajak anak untuk terlibat dalam kegiatan berwirausaha, sehingga anak dapat mempertimbangkan wirausaha sebagai pilihan karirnya, 3) Pengaruh lingkungan juga dapat menjadi faktor dalam menumbuhkan jiwa berwirausaha pada anak.

\section{Saran}

Beberapa saran yang dapat diberikan sebagai berikut: 1) Kedua orangtua baik ayah maupun ibu perlu menanamkan jiwa berwirausaha pada anak karena kedua orangtua memegang peranan penting dalam tumbuh kembang anak khususnya pada waktu usia dini, 2) Sebaiknya kedua orangtua melakukan komunikasi yang efektif dengan anak dan memberikan gambaran tentang berbagai jenis profesi dan lapangan yang ada di sekitarnya, 3) Orangtua perlu mengubah pola berfikir bahwa pada saat kondisi anak perlu diarahkan untuk menciptakan lapangan kerja bukan hanya mencari kerja karena zaman sekarang terjadi kesenjangan antara jumlah pencari kerja dengan tersedianya peluang kerja.

\section{DAFTAR PUSTAKA}

Daradjat, Zakiah. 1997. Pendidikan Agama dalam Pembinaan Mental. Jakarta: Bulan Bintang.

Goode, William J. 1995. Sosiologi Keluarga (The Family). Terjemahan Laila Hanom Hasyim. Jakarta: Bumi Aksara.

Helmawati. 2014. Pendidikan Keluarga (Teoretis dan Praktis). Bandung: Remaja Rosdakarya.

Norman, C. 2009. Konsep Kewirausahaan. (Online). (http://ciptonorman.com), diakses 15 Oktober 2016.

Salim, Mohammad Haitami. 2013. Pendidikan Agama dalam Keluarga: Revitalisasi Peran Keluarga dalam Membangun Generasi Bangsa yang Berkarakter. Yogyakarta: A-Ruzz Media.

Suryana. 2001. Konsep Kewirausahaan Dalam Mengembangkan Ide-ide Usaha. (Online). (http://www.blogekonomi.com), diakses 10 Oktober 2016.

Suryana. 2003. Kewirausahaan Pedoman Praktis, Kiat dan Proses Menuju Sukses. Jakarta: Salemba Empat.

Syarbini, Amirulloh, et.all. 2011. Psikologi Belajar. Jakarta: Rajawali Press

Tafsir, Ahmad. 2002. Pendidikan Agama dalam Keluarga. Bandung: Remaja Rosdakarya.

Tafsir, Ahmad. 2011. Metodologi Pengajaran Agama Islam. Bandung: Remaja Rosdakarya.

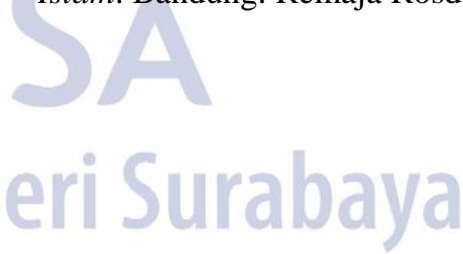

